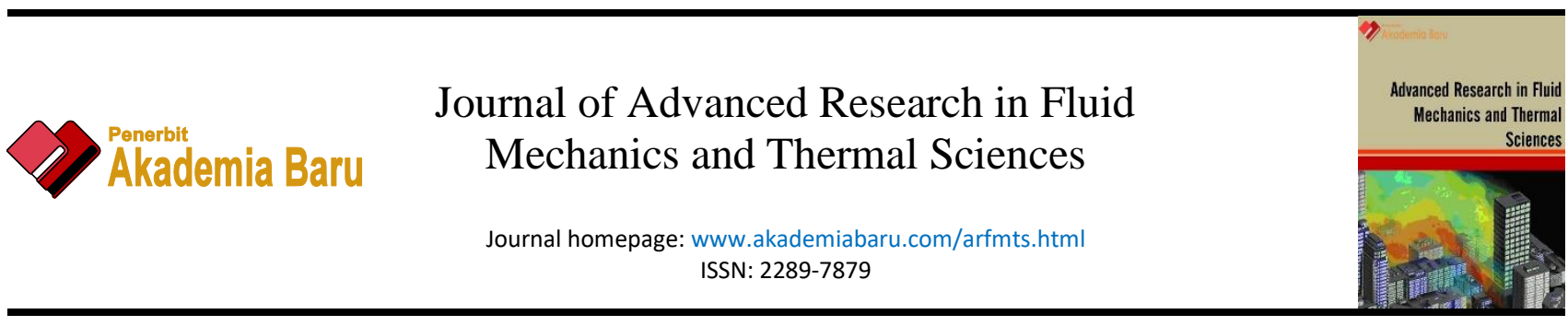

\title{
Utilization the Heat Pipe Heat Exchanger Techniques at Low Enthalpy Geothermal Energy to Coffee Drying Process
}

\author{
Imansyah Ibnu Hakim ${ }^{1, *}$, Nandy Putra ${ }^{1}$, Kukuh Tri Margono ${ }^{1}$, Yohanes Gunawan ${ }^{1,2}$ \\ Heat Transfer Laboratory, Department of Mechanical Engineering Universitas Indonesia, Kampus UI, Depok 16424, Indonesia \\ 2 Research and Development Center for Electricity, New, Renewable Energy and Energy Conservation Technology (P3tek KEBTKE), Ministry of \\ Energy and Mineral Resources (KESDM) Republic Indonesia
}

\section{ARTICLE INFO}

\section{Article history:}

Received 14 September 2019

Received in revised form 5 May 2020

Accepted 5 May 2020

Available online 15 August 2020

\section{ABSTRACT}

Coffee is one of Indonesia's main commodity which competes in international market. However, Indonesia's coffee production still faces some problems. One of the main problems is for the drying process. Moisture contents of coffee need to be reduced to $12 \%$. All this time, most coffee producers use conventional method by using heat source from sunlight. However, uncertain weathers become one of the factors which slows down the drying process. Therefore, the purpose of this research is to find and utilize an alternative energy to solve the drying process problem. One of energy sources which is possible to be used for those criteria is geothermal energy especially with low enthalpy that usually is used for daily activities such as bathing, cooking, and warming houses. In this research, Heat Pipe Heat Exchanger (HPHE) which consists of 42 straight heat pipes with staggered configuration is used for utilizing geothermal energy. The heat pipe has a length of $700 \mathrm{~mm}$ OD $10 \mathrm{~mm}$ with filling ratio of $50 \%$ and added by 181 pcs of aluminum with dimension size of $76 \times 345 \times 0.105 \mathrm{~mm}$ as a fin. Geothermal fluid is simulated by water that heated by 9000 watt heater. Temperature of hot water with range of 50,60 , and $70^{\circ} \mathrm{C}$ and air speed of $0.2,0.4,0.6 \mathrm{~m} / \mathrm{s}$ are variations for the experiment. The result shows that the highest effectiveness of HPHE is $78.8 \%$ with the temperature of $70^{\circ} \mathrm{C}$ and $0.2 \mathrm{~m} / \mathrm{s}$ air speed while the lowest effectiveness is $68.8 \%$ with the temperature of $50^{\circ} \mathrm{C}$ and $0.6 \mathrm{~m} / \mathrm{s}$ air speed. Other than that, the drying process with the temperature of $70^{\circ} \mathrm{C}$ and $0.6 \mathrm{~m} / \mathrm{s}$ air speed is the fastest while the slowest is at $50^{\circ} \mathrm{C}$ and air speed of $0.2 \mathrm{~m} / \mathrm{s}$. This result proves that increasing the temperature and air speed lead to the less time needed for the drying process.

\section{Keywords:}

Drying process, coffee, heat pipe, geothermal

Copyright @ 2020 PENERBIT AKADEMIA BARU - All rights reserved

\section{Introduction}

Coffee is one of the most commonly consumed beverages in the world [1]. Besides of its taste, consuming coffee in certain dose can prevent hypertension, coronary heart disease, inflammation,

\footnotetext{
* Corresponding author.

E-mail address: imansyah@eng.ui.ac.id
}

https://doi.org/10.37934/arfmts.74.2.4353 
and breast cancer [2,3]. Indonesia is the fourth biggest coffee producer which exports 11.1 million bags between 2016/2017. But Indonesia's coffee productivity is lower than Vietnam which has smaller area [4]. Low productivity of coffee in Indonesia is caused by post-harvest process especially drying which the moisture content is reduced up to $12 \%$ (w.b.) [5]. Most coffee producer in Indonesia still use sunlight energy which has some limitations especially due to the uncontrollable weather [6]. This uncontrollable situation causes drying process take longer drying period [7]. Also, open air sun drying has a potential of contamination with dust and insects [8]. Therefore, a new heat energy source is needed for the drying process.

Indonesia is a country with more than 200 volcanoes which are located along Sumatra, Java, Bali, and the eastern islands of the country with an expected potential of about $28 \mathrm{GWe}$ composed of 312 geothermal potential locations, but the utilization of this geothermal energy is still low [11,12]. Mostly, geothermal energy (GE) in Indonesia are characterized as low enthalpy geothermal and have shallow depth such as hot spring which is utilized for bathhouse, cooking, building heating, and agricultural drying [13-15]. Therefore, GE as a renewable energy can be used in drying processes as a heat source replacing the high energy costs of fossil fuels [16]. The distribution of GE in Indonesia is shown in Figure 1.

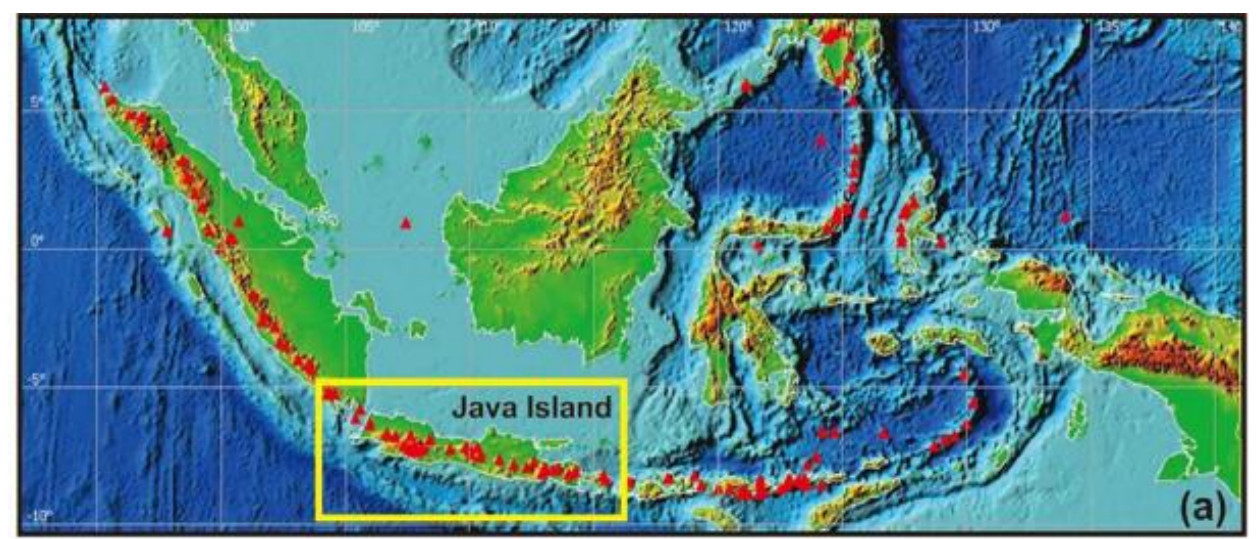

Fig. 1. Geothermal in Indonesia [17]

To optimize the utilization of GE, a heat transfer technology that has high efficiency/effectiveness is needed. Heat Pipe Heat Exchangers (HPHEs) have become very efficient because they are very compact and have the possibility for adjusting the transferred heat flux [18]. HPHEs are heat transfer devices which transfer heat passively without any moving parts, that work by phase change and vapour diffusion principal [19]. It consists of closed tubes that are filled with a proper working fluid. The heat pipes can be classified into three types: a conventional heat pipe (CHP), a two phase closed thermos syphon (TPCT) and an oscillating heat pipe (OHP) [20]. Therefore, the purpose of this research is to find and utilize alternative energy to solve the process problem in coffee beans drying. The alternative energy used in this experiment to the coffee beans drying is from geothermal energy and it will be extracted with heat pipe heat exchanger.

\section{Methodology}

\subsection{Proposed Coffee Drying System}

\subsubsection{Heat pipe design}

In this experiment, straight/tubular type heat pipes are used as a component of heat exchanger. Heat pipe length is $70 \mathrm{~cm}$ OD $1 \mathrm{~cm}$ while the length of the condenser is $35 \mathrm{~cm}$ and the length of the 
adiabatic side is $10 \mathrm{~cm}$ (Figure 2). The heat pipes are made from copper with the wick in the form of sintered copper and the filling ratio of water as working fluid is $50 \%$.

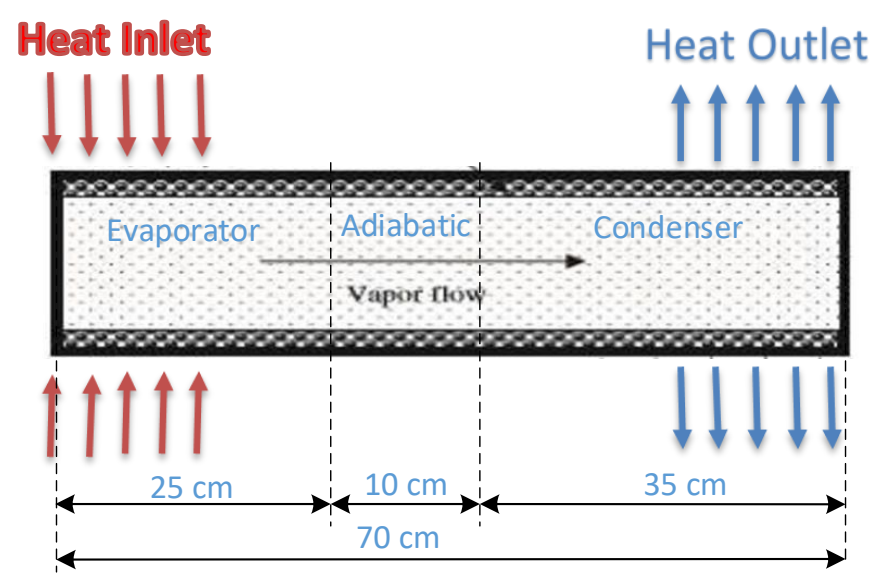

Fig. 2. Heat Pipe's Design

\subsubsection{Heat pipe heat exchanger design}

The HPHE used for this experiment is the same as in the previous study [22]. The HPHE consists of 42 tubular heat pipes with staggered arrangement and 181 pcs of the fin. The Fin is made from aluminium with a thickness of $0.105 \mathrm{~mm}$ with a size area of $76 \times 345 \mathrm{~mm}$. Glass wool and polyurethane is used as insulator in the adiabatic area. Figure 3 shows the HPHE used in this study.

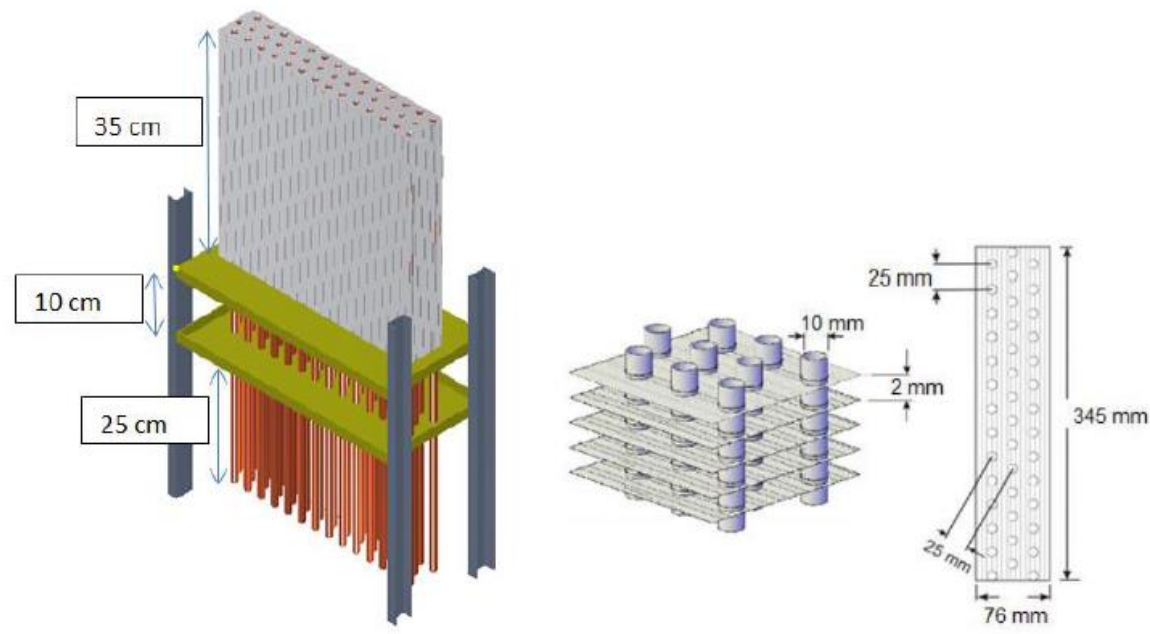

Fig. 3. Heat Pipe Heat Exchanger's Design

\subsubsection{Experimental setup}

In this experiment, geothermal fluid as the heat producer is simulated by heated water with a heater capacity of 9 kilowatts and flowed with a pump which is connected to the inverter. Air for drying is flowed with a fan connected to the inverter so that air flow can also be adjusted. HPHE and all supporting equipment that have been arranged are then assembled in experiment tools as shown in Figure 4. 


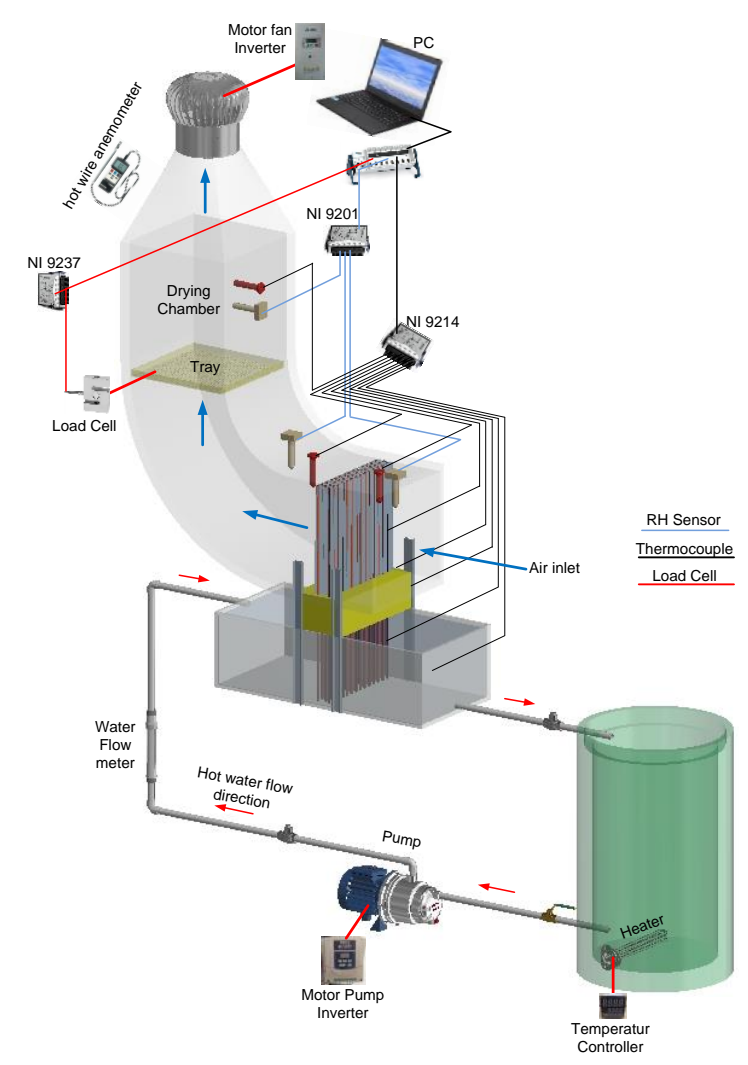

Fig. 4. Schematic diagram of coffee drying experimental set up

The sensor used and its placement can be seen in Figure 5. Type $\mathrm{K}$ thermocouple connected to $\mathrm{NI-CDAQ} 9214$ module is placed in the evaporator / inlet of the incoming hot water HPHE ( $\left.T_{\text {water, }}\right)$, Evaporator outlet / hot water that exits HPHE $\left(T_{\text {water,o }}\right)$, condenser inlet / hot air enters HPHE $\left(T_{\text {air }, i}\right)$, condenser outlet / hot air that exits HPHE $\left(T_{\text {air, }}\right)$, and air out drying tray $\left(T_{\text {air,o }}\right)$. The relative humidity sensor uses the THD-D Autonics type connected to NI-CDAQ 9201 module and placed in the HPHE condenser inlet $\left(\mathrm{RH}_{\mathrm{air}, \mathrm{i}}\right)$, HPHE condenser outlet $\left(\mathrm{RH}_{\mathrm{air}}, \mathrm{m}\right)$, and the drying chamber outlet tray $\left(\mathrm{RH}_{\mathrm{air}, \mathrm{o}}\right)$. Load Cell with the capacity of 1000 grams is connected to NI-cDAQ 9237 module and used for measuring the weight reduction of coffee in the drying tray. The tray area is $360 \times 360 \mathrm{~mm}^{2}$. Labview software is installed and used for signal recorded from the DAQ in real time.

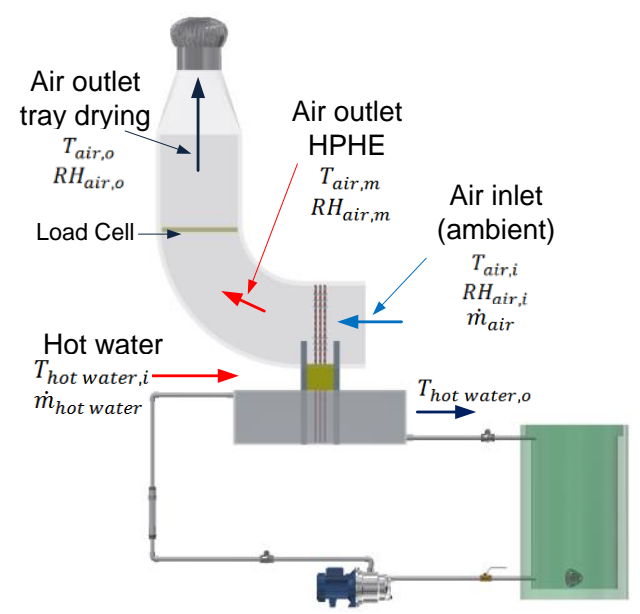

Fig. 5. Schematic placement of measuring instruments 


\subsection{Experimental Procedure}

Papandayan's coffee variety is chosen as a sample because it is located near to geothermal source, Papandayan volcano. A hundred grams of coffee are put into the tray for the drying process. This number of mass is chosen due to the dimension of the tray. This experiment is conducted for 1 hour after the experimental set up achieved stable temperature. The variable of this experiment is temperature $\left(50,60\right.$, and $\left.70^{\circ} \mathrm{C}\right)$ and air speed $(0.2,0.4$, and $0.6 \mathrm{~m} / \mathrm{s})$. While the flow of hot water is set at a value of 18 litres/second. This value is the value for optimal hot water flow in previous studies [22]. The condition of wet and dried coffee on tray is shown in Figure 6.

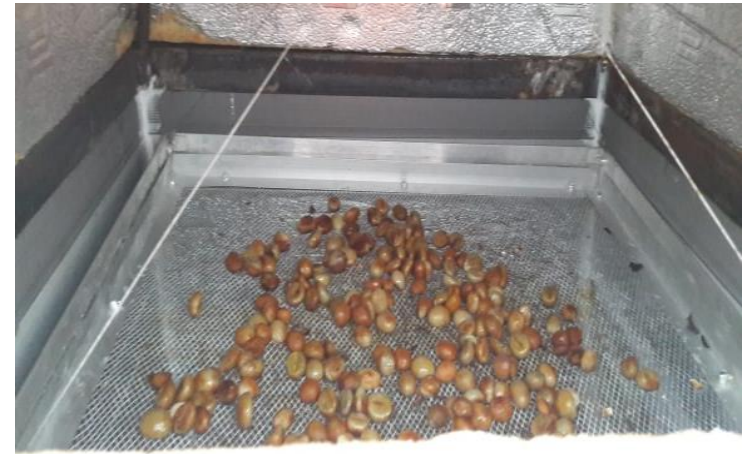

(a)

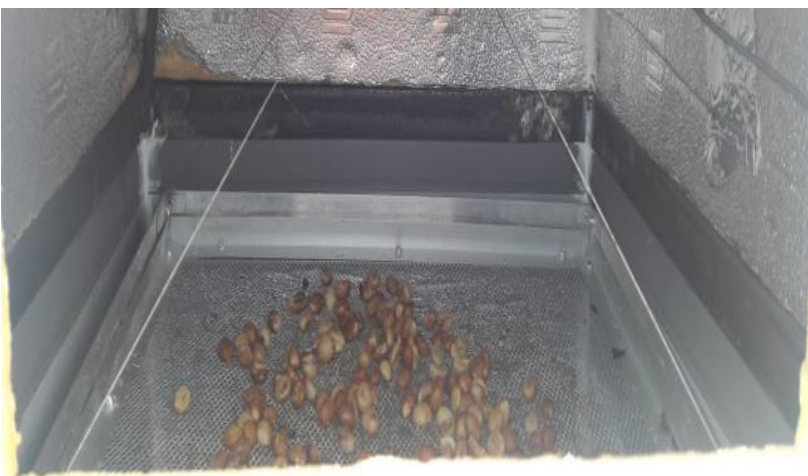

(b)

Fig. 6. (a) Wet coffee, (b) Dried Coffee

\subsection{Coffee's Moisture Content Measurement}

Moisture content is defined as how much water is contained in a commodity. Coffee's moisture content is measured with ISO 6673 standard about coffee's moisture content measurement with $105^{\circ} \mathrm{C}$ temperature [21]. To calculate the moisture content, there are two methods: dry base and wet base. The formula for the calculation of moisture content is shown in Eq. (1) and Eq. (2).

Moisture Content (dry basis) $=\frac{\text { weight of wet coffee-weight of drycoffee }}{\text { weight of drycofee }} \times 100 \%$

Moisture Content (wet basis) $=\frac{\text { weight of wet coffee-weight of dry coffee }}{\text { weight of wet coffee }} \times 100 \%$

\subsection{HPHE Effectiveness}

The effectiveness of heat exchanger is defined as the ratio of the actual heat transfer rate to the maximum possible heat transfer rate [23].

$\varepsilon=\frac{\dot{\mathrm{m}} \cdot C p \operatorname{air} \cdot(\operatorname{Th}(\text { air })-T c(\text { air }))}{\dot{\mathrm{m}} \cdot C p \min \cdot(\operatorname{Th}(\text { water })-T c(\text { air }))}$

In this research, minimum $\dot{m} \mathrm{Cp}$ is air's $\dot{\mathrm{m} C p}$. So, the equation will be

$\varepsilon=\frac{(T h(\text { air })-T c(\text { air })}{T h(\text { water })-T c(\text { air })}$ 


\subsection{Moisture Ratio}

Moisture Ratio is used for determining the time needed for the drying process. The formula for determining moisture ratio is

$M R=\frac{M-M_{e}}{M_{o}-M_{e}}$

$M \quad=$ Moisture content at certain time $(\%, \mathrm{db})$

$\mathrm{Me}_{\mathrm{e}} \quad$ = Moisture content equilibrium $(\%, \mathrm{db})$

$\mathrm{M}_{\mathrm{o}} \quad=$ Moisture content initial $(\%, \mathrm{db})$

$\mathrm{MR} \quad=$ Moisture ratio

While $\mathrm{Me}_{\mathrm{e}}$ is calculated by formula

$M_{e}=\frac{\left(a_{w} M_{m} c k\right)}{\left[\left(1-k a_{w}\right)\left(1+c k a_{w}-k a_{w}\right)\right]}$

$c=c_{o} \exp \left(\frac{c_{1}}{R T_{a b}}\right)$

$k=k_{o} \exp \left(\frac{k_{1}}{R T_{a b}}\right)$

where $a_{w}$ is water activity, $\mathrm{T}_{\mathrm{ab}}$ is absolute temperature $(\mathrm{K})$, and $\mathrm{R}$ is universal gas constant $(8.32 \mathrm{~kJ}$ $\left.\mathrm{mol}^{-1} \mathrm{~K}^{-1}\right)$. But, based on previous research that had been done by Purnomo et al., [24], because of the value of $\mathrm{RH}$ is unstable during the experiment and the value of $\mathrm{M}_{e}$ is too small, $\mathrm{M}_{\mathrm{e}}$ is negligible for finding MR. For coffee, the moisture ratio is reduced to $66.58 \%$.

\section{Results}

\subsection{The Condition of Temperature and Relative Humidity (RH)}

The temperature profile of the water enters the HPHE, water exits the HPHE, the air enters the HPHE (ambient), the air exits the HPHE or enters the drying tray, and the air out of the drying tray in this test can be seen in Figure 7(a). Hot water inlet area evaporator of HPHE is maintained at $50^{\circ} \mathrm{C} . \mathrm{A}$ steady state is achieved after the heater has been turned on for about 1 hour.

The temperature of hot water outside the evaporator area of the HPHE has different temperature approximately of $0.8^{\circ} \mathrm{C}$ with the temperature of hot water inlet the evaporator. This indicates that the HPHE evaporator is successful in absorbing heat from incoming hot water, the amount of which depends on the amount of air velocity or the amount of heat released in the HPHE condenser area. The heat released in the area of the HPHE condenser will be used to heat the inlet air that is used to dry the coffee beans.

The condition of RH in the system can be seen from Figure 7(b). As we can see, $\mathrm{RH}$ is getting lower as the temperature is increasing. From this condition, the air is being dry enough to do the drying process and reduce the moisture content of the coffee. 


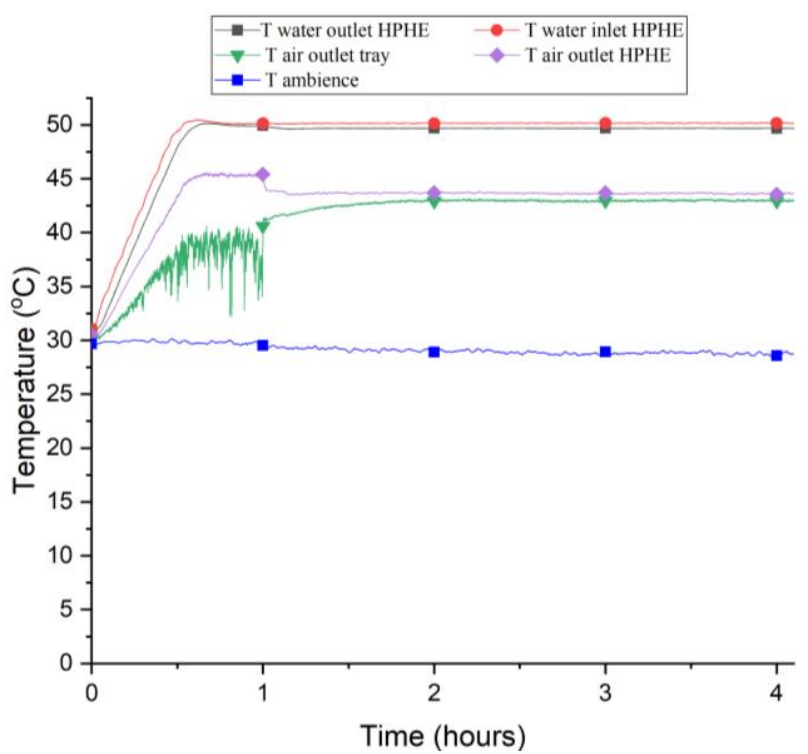

(a)

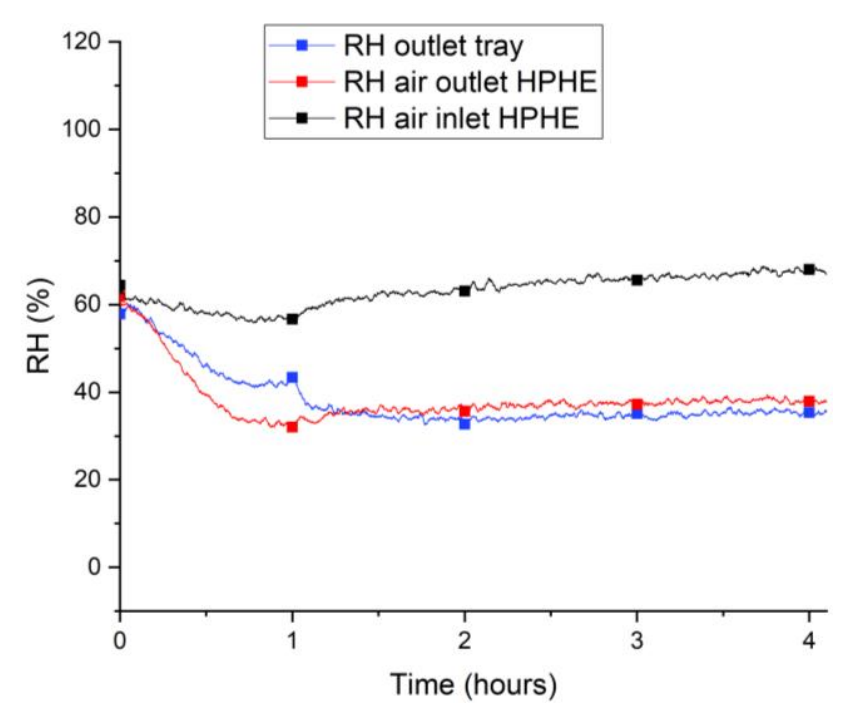

(b)

Fig. 7. (a) Temperature condition, (b) RH condition

\subsection{Change of Coffee Beans Mass Measured}

Heated air after passing through the HPHE condenser is used to dry the coffee beans that are in the drying tray. The air that passes through the coffee beans successfully evaporates water that is outside the skin and inside the coffee beans. This can be indicated that coffee beans experienced a decrease in weight after exhaling hot air during the drying process. The change of mass measured happened because the water contained in coffee is evaporated and transferred during the drying process. The change of coffee beans mass can be seen in Figure 8, wherefrom a hundred kg of coffee beans, the mass reduces approximately until 50 gram after 4 hours drying process.

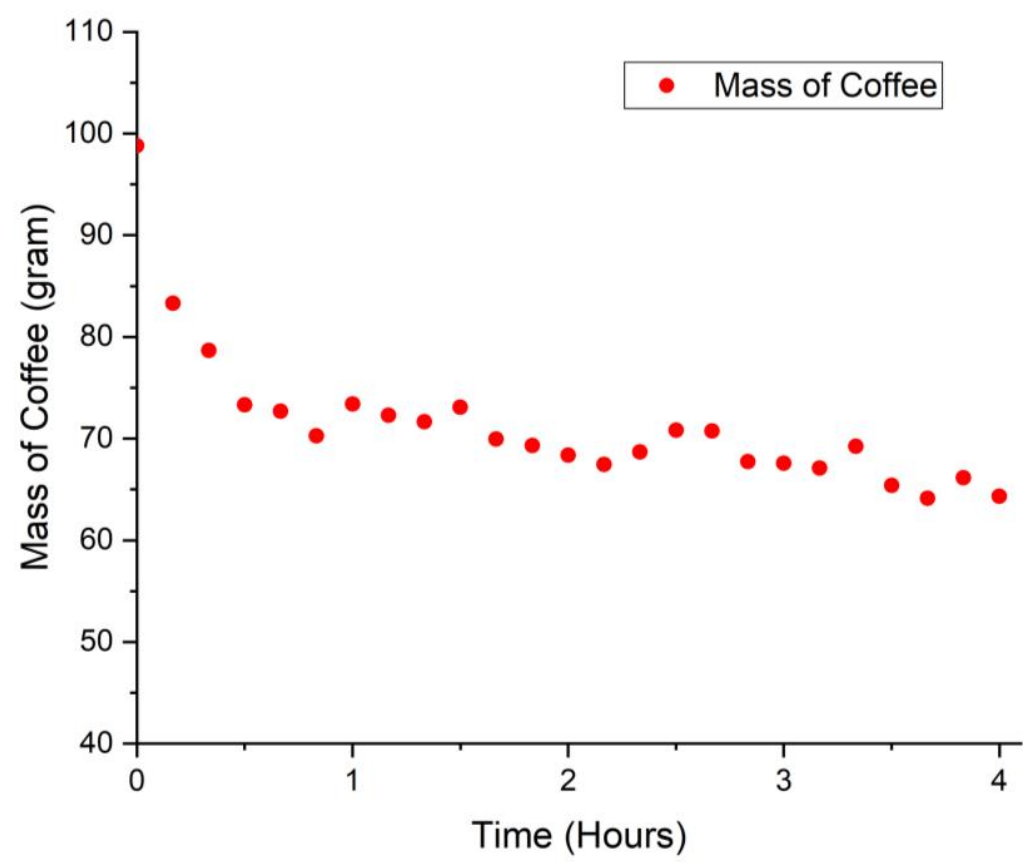

Fig. 8. Change of Mass Measured 


\subsection{Effectiveness of HPHE}

The performance of the HPHE system can be seen from the value of its effectiveness. From Figure 7(a), Eq. (3), and Eq. (4), it can be calculate the value of the effectiveness, and can be seen that the greatest effectiveness of HPHE occurs at variations of air velocity of $0.2 \mathrm{~m} / \mathrm{s}$ with a hot water temperature of $70^{\circ} \mathrm{C}$ and flow: $18 \mathrm{lpm}$ with the effectiveness of $78.8 \%$. While for the smallest effectiveness occurs at variations of air velocity of $0.6 \mathrm{~m} / \mathrm{s}$ with a hot water temperature $50^{\circ} \mathrm{C}$ and flow: $18 \mathrm{lpm}$ with effectiveness $67.3 \%$ (Figure 9). It can be seen that the increase in the temperature of the hot water received by the evaporator of the HPHE will increase the value of $\Delta T c$. However, increasing the speed of the air flow will reduce the value of $\Delta T c$. Because the convection heat transfer coefficient $(h)$ is a function of the fluid velocity, when the air velocity increases, the convection coefficient of the heat transfer of the HPHE condenser section will also increase. The HPHE system has the ability to transfer heat at a fixed optimum value. When the heat value (q) released in the HPHE condenser section remains constant, the convection heat transfer coefficient value increases because the air velocity increases. With a fixed area of heat $(A)$ heat transfer, according to the convection heat transfer equation: $q=h . A . \Delta T_{C}$, the value of $\Delta \mathrm{Tc}$ will decrease.

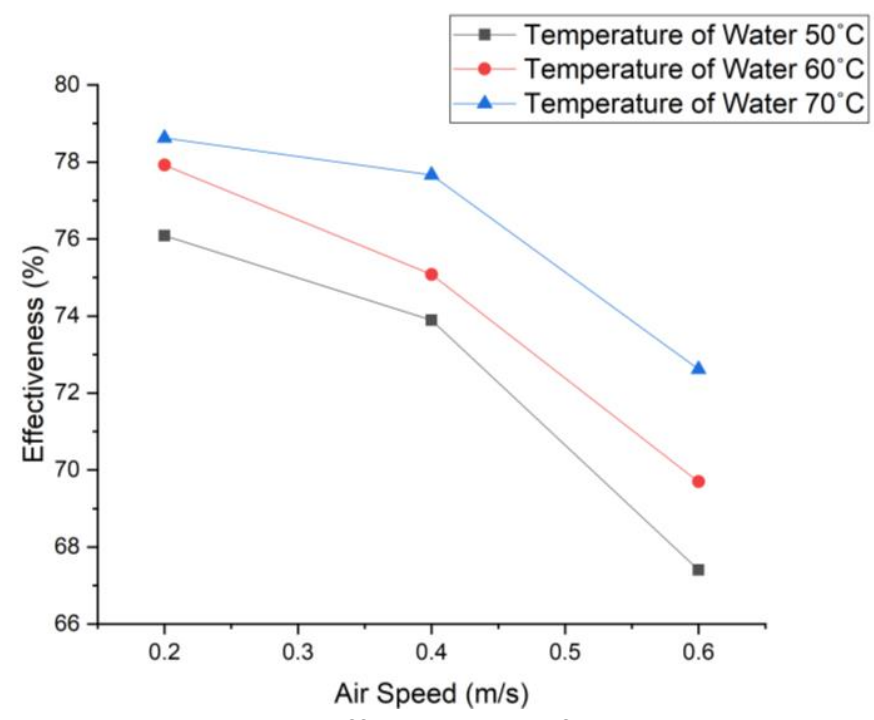

Fig. 9. Effectiveness of HPHE

\subsection{Reduction of Moisture Ratio (MR)}

The measured moisture content of the coffee beans before being placed into the drying tray is approximately $55 \%-56 \%$ of the wet base (w.b.). The mass of the coffee beans decreases, as can be seen in Figure 8, used to calculate the value of MR with used Eq. (1), Eq. (2), and Eq. (3) above. The trend of the decrease in the moisture ratio (MR) is used as an indicator to determine the duration of the drying process to achieve the expected water content of the coffee beans. After running the experiment for 4 hours, the result of the comparison of the MR value patterns of all the test variations can be seen in Figure 10. The results shows that the fastest drying process occur with condition temperature of $70^{\circ} \mathrm{C}$ with $v=0.6 \mathrm{~m} / \mathrm{s}$ while the slowest at the temperature of $50^{\circ} \mathrm{C}$ with $\mathrm{v}=0.2 \mathrm{~m} / \mathrm{s}$. It happened because drying process is affected by the relative humidity and temperature. The higher temperature will affect to the less $\mathrm{RH}$. The less $\mathrm{RH}$ means the less humidity in the air will affect to the faster drying process. 


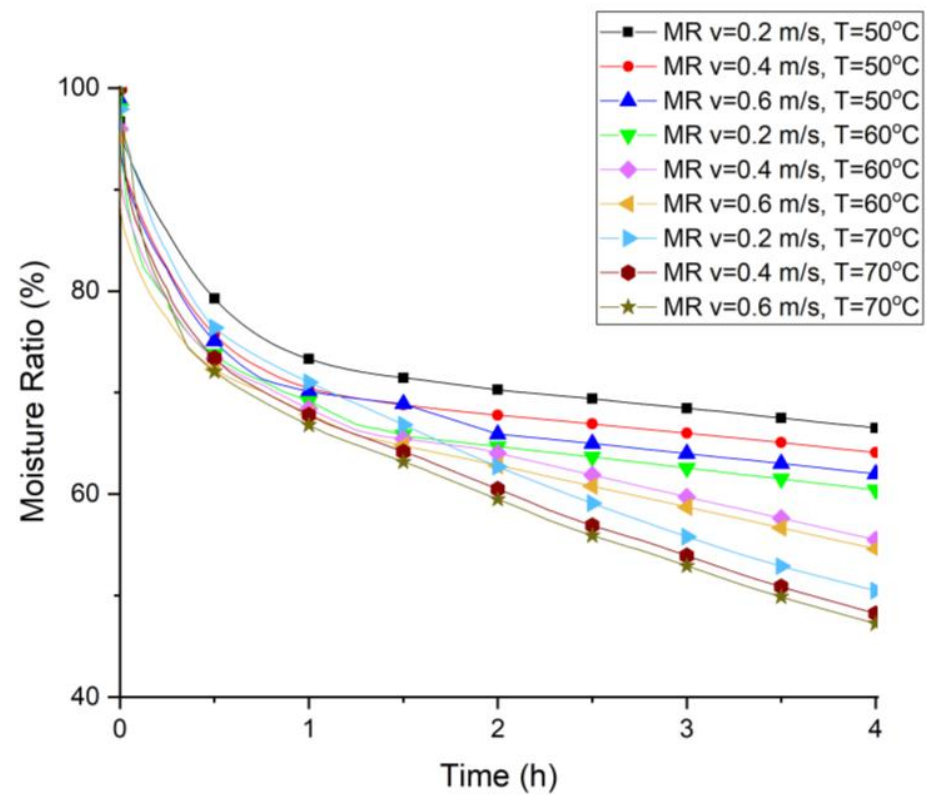

Fig. 10. Reduction of moisture ratio

\section{Conclusions}

The use of Heat Pipe Heat Exchanger with geothermal as source of energy for the drying process is suitable to be implemented to reduce the consumption of fuel and electricity as heat producer. The highest effectiveness of HPHE for the drying process in this experiment is $78.8 \%$ with the condition of the temperature of $70^{\circ} \mathrm{C}$ with air velocity of $0.2 \mathrm{~m} / \mathrm{s}$, while the lowest is $67.3 \%$ with the condition of the temperature of $50^{\circ} \mathrm{C}$ with air velocity of $0.6 \mathrm{~m} / \mathrm{s}$. The fastest drying process (reduction of moisture ratio) occurred when the experiment run at the temperature of $70^{\circ} \mathrm{C}$ with air velocity of $0.6 \mathrm{~m} / \mathrm{s}$ while the slowest occurred with the condition of the temperature of $50^{\circ} \mathrm{C}$ with air velocity of $0.2 \mathrm{~m} / \mathrm{s}$. Higher temperature and air speed will impact to less time needed for the drying process.

\section{Acknowledgement}

The author would like to thank Directorate of Research and community Engagements Universitas Indonesia (DRPM UI), for funding this research through the PITTA 2019 scheme with contract number NKB-0739/UN2.R3.1/HKP.05.00/2019.

\section{References}

[1] Montagnana, Martina, Emmanuel J. Favaloro, and Giuseppe Lippi. "Coffee intake and cardiovascular disease: virtue does not take center stage." In Seminars in Thrombosis and Hemostasis, vol. 38, no. 02, pp. 164-177. Thieme Medical Publishers, 2012.

https://doi.org/10.1055/s-0032-1301414

[2] Ciaramelli, Carlotta, Alessandro Palmioli, and Cristina Airoldi. "Coffee variety, origin and extraction procedure: Implications for coffee beneficial effects on human health." Food Chemistry 278 (2019): 47-55. https://doi.org/10.1016/j.foodchem.2018.11.063

[3] Stefanello, Naiara, Roselia Maria Spanevello, Sabina Passamonti, Lisiane Porciúncula, Carla Denise Bonan, Ayodeji Augustine Olabiyi, João Batista Teixeira da Rocha, Charles Elias Assmann, Vera Maria Morsch, and Maria Rosa Chitolina Schetinger. "Coffee, caffeine, chlorogenic acid, and the purinergic system." Food and Chemical Toxicology 123 (2019): 298-313. https://doi.org/10.1016/i.fct.2018.10.005

[4] ICO. "Annual Review 2016/17." International Coffee Organization, 2016. http://www.ico.org/Documents/Cy2017-18/Annual-Review-Website-E.Pdf. 
[5] Ghosh, Payel, and N. Venkatachalapathy. "Processing and drying of coffee-a review." International Journal of Engineering Research \& Technology (IJERT) 3, no. 12 (2014): 784-794.

[6] Ahmed, Naseer, Jagmohan Singh, Harmeet Chauhan, Prerna Gupta Anisa Anjum, and Harleen Kour. "Different drying methods: their applications and recent advances." International Journal of Food Nutrition and Safety 4, no. 1 (2013): 34-42.

[7] Lamidi, Rasaq O., Long Jiang, Pankaj B. Pathare, YaoDong Wang, and A. P. Roskilly. "Recent advances in sustainable drying of agricultural produce: A review." Applied Energy 233 (2019): 367-385.

https://doi.org/10.1016/i.apenergy.2018.10.044

[8] Helvaci, H. U., Abhay Menon, Levent Yurdaer Aydemir, Figen Korel, and G. G. Akkurt. "Drying of olive leaves in a geothermal dryer and determination of quality parameters of dried product." Energy Procedia 161 (2019): 108114.

https://doi.org/10.1016/i.egypro.2019.02.065

[9] Prakash, Om, Vinod Laguri, Anukul Pandey, Anil Kumar, and Arbind Kumar. "Review on various modelling techniques for the solar dryers." Renewable and Sustainable Energy Reviews 62 (2016): 396-417. https://doi.org/10.1016/j.rser.2016.04.028

[10] Fudholi, Ahmad, Kamaruzzaman Sopian, Mohd Hafidz Ruslan, M. A. Alghoul, and Mohamad Yusof Sulaiman. "Review of solar dryers for agricultural and marine products." Renewable and Sustainable Energy Reviews 14, no. 1 (2010): 1-30. https://doi.org/10.1016/i.rser.2009.07.032

[11] Bina, Saeid Mohammadzadeh, Saeid Jalilinasrabady, Hikari Fujii, and Nugroho Agung Pambudi. "Classification of geothermal resources in Indonesia by applying exergy concept." Renewable and Sustainable Energy Reviews 93 (2018): 499-506.

https://doi.org/10.1016/i.rser.2018.05.018

[12] Razzano, Francesco, and Maurizio Cei. "Geothermal power generation in Italy 2010-2014 update report." In Proceedings World Geothermal Congress 2015, pp. 19-24. 2015.

[13] Pikra, Ghalya, Nur Rohmah, Rakhmad Indra Pramana, and Andri Joko Purwanto. "The electricity power potency estimation from hot spring in Indonesia with temperature 70-80 C using organic Rankine cycle." Energy Procedia 68 , no. Supplement C (2015): 12-21.

https://doi.org/10.1016/i.egypro.2015.03.227

[14] Prasetya, Novrisal, Defry Erwinsyah Umra Lubis, Dharmawan Raharjo, Nenny Miryani Saptadji, and Heru Berian Pratama. "Smart geo-energy village development by using cascade direct use of geothermal energy in Bonjol, West Sumatera." In IOP Conference Series: Earth and Environmental Science, vol. 103, no. 1, p. 012004. IOP Publishing, 2017. https://doi.org/10.1088/1755-1315/103/1/012004

[15] Bayer, Peter, Guillaume Attard, Philipp Blum, and Kathrin Menberg. "The geothermal potential of cities." Renewable and Sustainable Energy Reviews 106 (2019): 17-30.

https://doi.org/10.1016/i.rser.2019.02.019

[16] Dinçer, Ibrahim, Adnan Midilli, and Haydar Kucuk, eds. Progress in Exergy, Energy, And the Environment. Springer, 2014.

https://doi.org/10.1007/978-3-319-04681-5

[17] Daud, Yunus, Wambra Aswo Nuqramadha, Fikri Fahmi, Rhyno Senbyla Sesesega, Surya Aji Pratama, and Arif Munandar. "Resistivity characterization of the Arjuno-Welirang volcanic geothermal system (Indonesia) through 3D Magnetotelluric inverse modeling." Journal of Asian Earth Sciences 174 (2019): 352-363.

https://doi.org/10.1016/i.jseaes.2019.01.033

[18] Burlacu, Andrei, Gavril Sosoi, Robert Ștefan Vizitiu, Marinela Bărbuță, Constantin Doru Lăzărescu, Vasilică Ciocan, and Adrian Alexandru Șerbănoiu. "Energy efficient heat pipe heat exchanger for waste heat recovery in buildings." Procedia Manufacturing 22 (2018): 714-721. https://doi.org/10.1016/j.promfg.2018.03.103

[19] Jouhara, Hussam, Amisha Chauhan, Theodora Nannou, S. Almahmoud, Bertrand Delpech, and Luiz C. Wrobel. "Heat pipe based systems-Advances and applications." Energy 128 (2017): 729-754.

https://doi.org/10.1016/j.energy.2017.04.028

[20] Srimuang, Wasan, and Pipatana Amatachaya. "A review of the applications of heat pipe heat exchangers for heat recovery." Renewable and Sustainable Energy Reviews 16, no. 6 (2012): 4303-4315. https://doi.org/10.1016/i.rser.2012.03.030

[21] 8589ISO. International Standard International Standard: ISO 14644, 2007 (2013).

[22] Hakim, Imansyah Ibnu, Nandy Putra, and Yohanes Gunawan. "Experimental study for heat pipe applications on low enthalpy geothermal energy utilization for agricultural products dryers." Journal of Advanced Research in Fluid 
Mechanics and Thermal Sciences 56, no. 1 (2019): 68-77.

[23] Firouzfar, E., Mohammad Soltanieh, S. H. Noie, and M. H. Saidi. "Investigation of heat pipe heat exchanger effectiveness and energy saving in air conditioning systems using silver nanofluid." International Journal of Environmental Science and Technology 9, no. 4 (2012): 587-594. https://doi.org/10.1007/s13762-012-0051-9

[24] Purnomo, C. W., and S. Indarti. "Modification of indirect solar dryer for simplicia production." In IOP Conference Series: Earth and Environmental Science, vol. 120, no. 1, p. 012026. IOP Publishing, 2018. https://doi.org/10.1088/1755-1315/120/1/012026 